\title{
Study on the Utility Evaluation and Countermeasures of Consumer Coupons Under the Background of COVID-19
}

\author{
Shubo Jiang ${ }^{1}$, Muyang $\mathrm{Ni}^{2 *}$ \\ ${ }^{1}$ School of Economics, Harbin University of Commerce, Harbin, Heilongjiang 150028, China \\ ${ }^{2}$ School of Economics, Harbin University of Commerce, Harbin, Heilongjiang 150028, China \\ *Corresponding author. Email: 2420487409@qq.com
}

\begin{abstract}
Since the outbreak of novel coronavirus pneumonia, the sales of non-essential commodities, catering industry and entertainment industry have been significantly affected. In order to effectively deal with the impact on the epidemic of consumption, various regions and departments have successively issued policies and measures to expand consumption. The issuance of consumer coupons is one of the major measures. This paper analyzes the utility of consumer coupons and the peculiarities of China's environment, and researches the feasibility of issuing consumer coupons based on the analysis results. Finally, it proposes specific countermeasures and suggestions for the problem in the issuance, which provide a theoretical basis of the issuance of consumer coupons.
\end{abstract}

Keywords: Consumer coupons, multiplier effect, cash substitution effect, demand elasticity

\section{INTRODUCTION}

In March 2020, 23 departments including the National Development and Reform Commission, the Central Propaganda Department, the Ministry of Finance, the Ministry of Commerce, and the People's Bank of China jointly issued the "Implementation Opinions on Promoting Consumption Expansion and Quality, Accelerating the Formation of a Strong Domestic Market", focusing on improving consumption Environment, improve the consumption promotion system and mechanism, and help form a strong domestic market. Various localities and departments have successively introduced policies and measures to expand consumption, including the introduction of consumer coupons. Consumption can directly and quickly boost the economy, digest the surplus products, realize the withdrawal of funds from manufacturers and circulation links, and foster economic growth. At the same time, the issue of consumption of the disadvantaged groups is conducive to improving the quality of life of low-income groups. This paper analyzes the effect and feasibility of issuing consumer coupons, which is of great significance to local governments in issuing consumer vouchers.

\section{TYPES AND EFFECTS CONSUMER COUPONS}

\subsection{Types of Consumer Coupons}

Consumer coupons, as a kind of consumption ticket, issued to the public for the purpose of stimulating domestic demands, stimulating economy and expanding employment. The amount and objects of distribution will vary from different regions[1]. When the economic recession makes the consumption ability and consumption demand of the people decline, the consumption voucher can be used as an economic policy tool.

As a special method to promote consumption under unusual conditions, consumer coupons are mostly selfissued by local governments in response to crises.[2]. Consumer coupons is a kind of special voucher and one of the tools to implement monetary policy. Although the main purpose of issuing consumer coupons is to promote consumption growth, it can also be used as a social relief tool[3]. Based on the views of the above scholars, consumer coupons can be classified according to different dimensions into several categories:

(1)From the scope of the issuance of consumer coupons, it can be divided into generalized system of consumer coupons and special system of coupons. The issuing scope of generalized system of consumer coupons covers all personnel in the issuing area. For example, Beijing issued free electronic coupons worth 10 million yuan worth of Huimin cultural consumption to Beijing residents in 
August 2016, which has the effect of subsidizing mass cultural consumption. On the contrary, special system of coupons are issued for special groups. For example, in 2009, Hangzhou issued 700 million yuan of consumer coupons for specific groups of people in two times.

(2)From the nature of the issuance, it can be divided into dividend-type consumer coupons and non-profit-type consumer coupons.

(3)From the perspective of distribution subject, it can be divided into government issuing consumer coupons, government and enterprise joint issuing consumer coupons, enterprise issuing consumer coupons, etc.

(4)From the specific distribution object and application scope of consumer coupons, it can be divided into government consumer coupons, social consumer coupons, transfer consumer coupons, shopping consumer coupons, tourism consumer coupons, education and training consumer coupons, etc.

\subsection{Effects of Consumer Coupons}

\subsubsection{Multiplier effect of consumer coupons}

The application of multiplier effect on economic activities can be understood as the change of a variable's input on the total economic volume and its response degree, that is, the change of investment will cause several times of changes in income or consumption. The government will expand the residents' ability to consume. From the multiplier $=1 /(1-\mathrm{mpc})$, MPC is the marginal propensity to consume, which is the ratio of the current consumption to the current income. The multiplier theory can be utilized to infer the proportion of residents used to increase consumption in each unit of income. Different types of consumer coupons can bring different multiplier effects. When consumer goods are necessities, the elasticity of demand is small, that is, such goods are not sensitive to price changes, and even if the price is reduced, it is difficult to increase the demand rapidly in a short period of time. When the consumer goods are tourism, education and training, household appliances and other goods with large demand elasticity, the demand is more sensitive to the change of price. Once the price is decreased, the demand will expand rapidly and stimulate the economic vitality.

\subsubsection{Cash substitution effect of consumer coupons}

The cash substitution effect of consumer coupons refers to that residents save part of the cash replaced by consumer coupons and do not choose to expand consumption, which makes it difficult to achieve the effect of stimulating the economy. From the perspective of income level, the cash substitution effect of consumer coupons is more obvious in low-income groups. Because they are worried that the future economic situation is not optimistic, they tend to save more, which will weaken the multiplier effect of cash substitution effect of consumer coupons. It's not conducive to stimulating consumption and restoring economic vitality. In terms of the types of goods purchased, the cash substitution effect of consumer coupons is more noticeable in commodities with small demand elasticity. For commodities with high elasticity of demand, such as education and tourism vouchers, the consumption amount is usually large. On the basis of partial preferential treatment of consumption coupons, a part of cash still needs to be filled for consumption. The effect of cash substitution will not affect the multiplier effect of consumer coupons.

\section{ANALYSIS OF THE PARTICULARITY OF ISSUING CONSUMER COUPONS IN CHINA}

\subsection{COVID-19 has a short-term impact on China's economy}

Affected by the epidemic situation, the tertiary industry suffered a huge influence and recovered slowly. According to the proportion of production factors in economic activities, the catering industry is a typical labor-intensive industry, and human cost accounts for the majority of its total cost. Affected by COVID-19, the catering industry still has to bear the expenses of house rent, deterioration of food materials, employment wages and other expenses without sales revenue, which results in many restaurants operating difficulties and even bankruptcy. The leisure and entertainment industry (KTV, cinema line, etc.) has the synchronization of production and consumption. In the environment of limited travel and home anti epidemic, they still need to pay fixed rent and employee compensation without income, which brings great obstacles to the recovery of the industry in the future.

The effective credit demand of banks has declined and the quality of credit assets has deteriorated. Affected by the epidemic situation, the stagnation of social production activities will reduce residents' income and lead to the decline of consumption demand. This will undoubtedly cause enterprises to delay their plans to expand production and reduce the demand for loan funds. Banks have already paid a certain amount of foreign aid costs to enterprises in the epidemic area by reducing interest rates and reducing fees. The decline of credit demand will further decrease the profitability of banks and increase the operating pressure of banks. 


\subsection{Transformation of China's Economic Structure}

After the outbreak of the international financial crisis, the world economic structure has continued to undergo profound changes. The slowdown in global economic growth has indirectly reduced the external demand for Chinese exported products, and its role in driving China's economic growth has weakened. China's traditional demographic dividend is gradually decreasing, and the pressure on the ecological environment continues to expand. Energy, resources and the environment are becoming important factors restricting economic development. At present, China's model of relying on factor input and scale expansion is unsustainable. It is urgent to transform the mode of economic development, shift from high-speed growth to high-quality growth, transform the growth momentum, and improve economic efficiency.

$\mathrm{Wu}$ Jiaxi and $\mathrm{Li}$ Huashen believe that enterprise transformation and upgrading can be understood from two levels: transformation and upgrading. Transformation can be understood as the transition from one state to another, that is, the transition between different industries or the transition between different development models[4]. The current lack of high-end talents and technical support restricts the transformation and upgrading of enterprises to a certain extent. High-end talents can provide the necessary technical and management support for the transformation of enterprises. Encouraging high-educated and high-quality social talents to start businesses can also provide new impetus for transformation and upgrading.

With the establishment of the market economy system, China has constantly improve financial laws and supervision. The government has given full play to its functions and attached importance to the construction of social credit system, which has a certain effect on the prevention of systemic financial risks. At the same time, many trade frictions caused by external economic imbalances have forced China to reduce its trade surplus and adopt a certain trade balance strategy. With increasing uncertainties of the external environment, China's industrial structure should be continuously adjusted in the direction of technological innovation and industrial innovation.

\section{THE NECESSITY OF ISSUING CONSUMER COUPONS}

\subsection{Short Term Effects of Consumer Coupons}

Consumer coupons are more likely to produce effects on commodities with higher demand elasticity because commodities with high demand elasticity are sensitive to price, which refers to household electricity consumer coupons, tourism consumer coupons, education coupons, etc. The short-term effect of consumer coupons is not limited to increase consumption in the short term, but a buffer period for the recovery of consumption confidence in the future. The issuance of consumer coupons can effectively stimulates consumer's purchase desire and make consumer market present a relatively optimistic situation. The prosperity of the consumer market can enhance the production confidence of enterprises, reduce the number of layoffs and stabilize the unemployment rate. At the same time, it is conducive to enhancing the consumption expectation of residents and increasing the current consumption. Issuing consumer coupons is benefit for the change of residents' living conditions to a certain extent. Furthermore, it can relieve the pressure of lowincome and poor groups. As a policy of benefiting the people, it also can convey the government's care and maintain social stability.

\subsection{Long Term Impact of Consumer Coupons}

Different from other subjects, consumer coupons issued by the government are more directional. It can be used to achieve policy objectives or promote social equity. The government issues food consumer coupons to the poor and low-income groups, which not only improves residents' lives and maintains social stability, but also completes the process of readjusting factor income. From the perspective of social utility, the issuance of consumer coupons can stimulate residents' consumption and give consideration to social fairness and efficiency, so it has policy advantages.

Li Yingsheng believes that social equity can be understood as the reasonable distribution of political, economic and other interests among all members of the society, including equality of rights, reasonable distribution, equality of opportunities and judicial justice[5]. Whether a social policy can be implemented not only depends on the common needs, but also takes into account the protection of special vulnerable groups. In such an environment of macroeconomic depression due to the impact of the epidemic, by issuing consumer coupons, the government can help low-income people to tide over the difficulties which is an effective means to balance social fairness and efficiency.

\section{POLICY RECOMMENDATIONS}

\subsection{Improve Laws and Regulations and Standardize Distribution Channels}

The issuance of consumer coupons may conflict with the existing legal framework. Local governments can only achieve good results by issuing consumer coupons based on their actual conditions. However, except for the people's Bank of China, it is illegal for any entity to issue consumer coupons. At the same time, regulatory measures should be set up to ensure the fairness of the issuance process and the transparency of the collection process. 


\subsection{Add More Targeted Designs in the Process of Using Consumer Coupons}

For a single subject to issue consumer coupons, not only the capital cost required is relatively large, but also the effect is somewhat unsatisfactory. At present, the main body of issuing consumer coupons in the market is the government, which often brings a great financial burden in order to make the policy effect. The government can consider issuing consumer coupons jointly with enterprises, which can not only relieve the financial pressure and stimulate consumption, but also solve the problem of low credibility of enterprises issuing coupons. For companies, government recognition is also conducive to enhancing their positive image.

In the use of consumer coupons, it is difficult to avoid the substitution effect. If consumer coupons are used only to stimulate the economy, then the role of promoting the economy is very limited. So we can do some design on use pattern ,For example, it is required to match cash with consumer coupons, which helps to reduce the situation that residents choose to save cash and only use consumer coupons for consumption.

\subsection{Identify the Issuing Objects of Consumer Coupons and Improve the Marginal Effect of Consumption Coupons}

From the perspective of the income level of the issuers, if the low income person holds the consumer coupons, the issuance coupons has a strong cash substitute effect. because their economic conditions can only meet the needs of life, after residents use consumer coupons, they will replace the cash used to buy goods with savings, rather than expanding consumption. It has a certain social security nature. The cash substitution effect of middle and high-income groups is relatively weak. Issuing consumer coupons will increase their consumption and choose to buy goods with higher elasticity of demand, which will lead to better economic development. For goods with high elasticity of demand, such as education, training and tourism, The marginal propensity to consume differs little among these groups, so the scope of distribution can be appropriately relaxed. In terms of the target age, the elderly and students have a strong consumption tendency. Issuing consumer coupons will promote the consumption of these two groups.

\subsection{Design Supporting Policies to Play a Role in Increasing Efficiency}

Consumer coupons have intertemporal substitution. The issuance of consumer coupons alone may stimulate consumption in the short term and restore consumer confidence, but it cannot solve the problem of insufficient power in economic development. The intertemporal substitution refers to the issuance of consumer coupons to help consumers choose long-term consumption in the current period, but this part of the demand cannot be copied. Durable goods can be used for a long time after purchase, and they will not be replaced frequently. However, the continuous increase in consumer demand can only be achieved by raising the level of economic development and increasing residents' income. Therefore, in order to solve the problem of insufficient economic development momentum, it is necessary to combine shortterm effective consumer coupons with long-term development supporting measures.

\section{CONCLUSION}

Using consumer coupons to stimulate the economy should be regarded as a short-term emergency economic policy. The fundamental purpose of issuing consumer coupons is to stimulate demand and activate consumption frozen by the epidemic in the short term. This method has some effects, but it will not have a long-term effect. Promoting consumption growth requires combining long-term arrangements with short-term measures. The short-term goal mainly focuses on consumption replenishment, which is to replenish the stock that has been delayed or disappeared due to the epidemic. The long-term goal should focus on the release of consumption potential. Consumption growth should focus on improving the consumption system and consumption environment, and establishing a more complete long-term mechanism for consumption growth. Eventually promote the growth of emerging consumption, soft consumption, and implicit consumption. From a consumer's point of view, getting consumer coupons and spending within the specified time can stimulate consumer demand. However, the continuous increase of personal consumption willingness is largely affected by expectations of future income. As the epidemic has not yet completely ended, consumer willingness and job prospects are closely related.

\section{ACKNOWLEDGMENT}

Support by Research Project of Harbin University of Commercial (18XN038).

\section{REFERENCES}

[1] Shen Mengying, Dictionary of neologisms and neologisms in 60 years of new China: $[\mathrm{M}]$. Chengdu: Sichuan publishing group, Sichuan Dictionary Publishing House.

[2] Jiang Zhengyin, A review of the issue of consumer coupons in China [J]. National business information (Research on economic theory), (17) (2009) 142-144 
[3] Wang Diandian, The effect of consumption coupons on promoting domestic demand: a case study of Hangzhou tourism consumption Coupons [J]. Operation and management, (06) (2010) 32-33

[4] Wu Jiaxi, Li Huashen, Investigation report on the transformation and upgrading of small and mediumsized enterprises in Zhejiang Province[J]. Management World, (08) (2009) 1-5+9.

[5] Li Yingsheng, The value basis of China's social policy reform and Innovation -- social equity and social policy [J]. Social science, (03) (2019) 76-88 